\title{
Higher Secondary Level Students' Attitude toward Use of E-Learning Materials in Health and Population Education
}

Bishnu G.C.*

\begin{abstract}
The study aimed to find out the "student's attitudes towards the use of e-learning materials in health and population education" at higher secondary level. The study adopted descriptive and quantitative survey design. In order to collect information, a set of attitude scale was used for 200 students of higher secondary level in the Kathmandu valley. The collected data were organized, tabulated, analyzed and interpreted by using the simple statistical tools such as percentage and $\chi 2$-test at 0.05 level of significance. The result of the study showed that the school students have sufficient e-learning tools with suitable existing situation for teaching and learning health and population education. The students have positive attitude towards the use of e-learning materials in health and population education. Most of the students agreed that the e-learning tools are very useful for higher achievement as well as higher study, as they provide basic concept with motivation.
\end{abstract}

Keywords: hardware, software, learning, virtual learning, multimedia

\section{Introduction}

E-learning, a new way of study different from traditional face-to-face learning, is defined as an innovative way of conducting learning activity at flexible times and places through the internet (Sparacia, et al., 2007). Normally e-learning includes most kinds of electronically supported learning and teaching (Mayes, 2004). Web based learning, Internet based learning and Computer based learning are all frequently used terms to mean e-learning (Horton, 2001).

The term 'e-learning' has existed since 1999 in teaching learning. Other words also began to spring up in search of an accurate description such as "online learning" and "virtual learning". However, the principles behind e-learning have been well documented throughout history, and there is even evidence which suggests that early forms of e-learning existed as far back as the $19^{\text {th }}$ century (Zeitoun, 2008).

E-learning includes all learning (formal as well as informal) managed through electronic devices for delivery. More precisely, e-learning encompasses both internet based learning and computer based learning, which consists of the components of online learning (Horton, 2001).

Hardware and software are applied to produce and share learning materials for students. Examples of hardware includes: Video input (laptop), video output (monitor or screen), sharing devices (pen drive, mobile), Software is used to produce and share learning materials through different calculation (Selim, 2008).

In 1924, the first testing machine was invented. This device allowed students to test themselves. Then, in 1954, BF Skinner, a Harvard professor, invented the "teaching machine", which enabled schools to administer programmed instruction to their students. It was not until 1960, however, that the first computer based training program was introduced to the world. This computer based training program (or CBT program) was known as PLATO-programmed logic for automated teaching operations. It was originally designed for students attending the University of Illinois, but ended up being used in schools throughout the area (Mayes, 2004).

The first MAC in 1980s enabled individuals to have computers in their homes making it easier for them to learn about particular subjects and

* Lecturer, Health and Population Education Department, TU, Kirtipur 
develop certain skill sets. Then, in the following decade, virtual learning environment began to truly thrive, with people gaining access to a wealth of online information (Kaling, 2007).

Recent figure from the Nepal authority show that around $24 \%$ of Nepali people now have access to some form of internet connection. An NTA report, however shows that only around $6 \%$ of the internet users have access to a trustworthy internet connection (wireless modem, optical fibre, cable modem, ADSL, CDMA). It is reported that $93 \%$ of the 6.4 million internet users in Nepal are still using unreliable and low-quality internet connection based on GPRS, EDCE and WCDMA technologies. These technologies are used in mobile phones. The report shows that $0.23 \%$ of the internet users still use dial up internet. Internet service providers in Nepal only have a market share of less than $2 \%$. N Cell and Nepal Telecom- both of whom are also voice operators collectively have a market share of $98 \%$. Nepal has been ranked in the 142th position among 159 countries in the e-learning development index (IDI) 2010 published by the International Telecommunication Union (ITU), the UN agency for information and communication technologies. The ranking is based on development of information technology and telecom sector of 2008. Nepal was ranked $141^{\text {st }}$ position in the IDI in 2007 (Sapkota, 2015).

MOE has implemented some of the programs related to e-learning in education. Some NGOs have developed interactive digital learning materials for the school students in mathematics. Under the matching grant schemes (2007 to 2010), DEO provided 2 computers and one printer to 3038 schools (DEO, 2010). Under the Formative Research Project of Education for All program 2004-2009, MOE provided one computer and one printer to each 62 schools. Besides, some NGOs, trusts and individuals have provided computers and other accessories to some schools and basic computer training to teachers (e-learning in Education Master Plan 2013), during the fiscal year 2010 and 2011, the government of Nepal has supported for e-learning related infrastructure and internet connectivity to 785 schools. In addition, DOE provided internet connectivity to 85 secondary schools to conduct distance education program for secondary level (MOE, 2013).

The use of web-based teaching materials, multimedia, CD-ROMs, e-mail, educational animation etc. have all been used and being used extensively in developed countries for learning purpose. However, the concept is somehow new to the developing country like Nepal. Nepal's education system relies mostly on the traditional approach to learning, though in recent years e- learning is being adopted in cities (MOE, 2013). MOE accesses the different policy and programme related to e-learning in school level. According to IT policy (2010), SSRP (2009-2015), and three year plan 20112013, GON has provided some policy and integration of e-learning in education (MOE, 2013).

Higher secondary level health and population education subjects are completely based on theory, research, contemporary issues, scientific components and quantitative data. E-learning materials like Google drive, you tube, DVD, LMS and so many are being used specially while learning the calculation of morbidity, fertility, mortality, disease prevalence rate, construction of table, graphic presentation etc. related to health and population components. It is also used to learn human anatomy, physiology, sexual and reproductive health, HIV and AIDS, STDs, nutrition, disease prevention, environmental health and health care. So, E-learning as a modern teaching material is useful and attractive for students of higher secondary level health and population education. 


\section{Objectives of the study}

The main objective of this study was to find out the attitude of students towards the use of e-learning materials at higher secondary level in health and population education subject.

\section{Methods of the study}

This study was based on quantitative and descriptive survey design. The higher secondary level health and population education students of Kathmandu valley in the academic year 2073/2074 were the population of this study. Altogether 200 students from ten higher secondary level were the samples of the study. Equally 20 students from each higher secondary school/college studying health and population education were sampled for this study. The convenient sampling technique was applied for the selection of higher secondary schools/college while purposive sampling technique was used for the selection of students. Edward's three point attitude scale with three alternatives (Agree, Neutral and Disagree) was applied as the main tool for data collection.

\section{Results}

The significance of each statement was tested by computing corresponding $\chi^{2}$-value and comparing them with tabulated $\chi^{2}-$ value 5.991, the value of $\chi^{2}$ at 0.05 level of significance with two degrees of freedom. If the calculated $\chi 2$ - value exceeded the tabulated $\chi^{2}$ - value then the statements were considered to have been significant. The gathered data were analyzed, the percentage score of each statement was determined and interpreted by using the conceptual understanding of the study.

\section{Opinion of higher secondary level students towards e-learning}

The obtained score of students opinions are represented in percentage and $\chi^{2}$ - value. The response that has greater than $50 \%$ opinion score is considered as positive opinion and below $50 \%$ opinion score is considered as negative opinion. The detailed analysis of the students attitude is given in the following table.

Student's attitude score with their percentage and $\chi^{2}$ - value towards E-learning $(N=200)$

\begin{tabular}{|c|c|c|c|c|c|c|c|c|c|}
\hline S.N. & Statements & $\begin{array}{c}\text { No. of } \\
\text { students }\end{array}$ & Agree & $\%$ & Neutral & $\%$ & Disagree & $\%$ & $\begin{array}{c}\chi^{2-} \\
\text { value }\end{array}$ \\
\hline 1 & $\begin{array}{l}\text { Using computer at school/ } \\
\text { college improves my learning. }\end{array}$ & 200 & 133 & 66.5 & 26 & 13 & 41 & 20.5 & 100.69 \\
\hline 2 & $\begin{array}{l}\text { E-learning makes learning } \\
\text { more interesting. } \\
\text { I can get access to computers }\end{array}$ & 200 & 144 & 72 & 6 & 3 & 50 & 25 & 149.08 \\
\hline 3 & $\begin{array}{l}\text { at school/college whenever I } \\
\text { need. }\end{array}$ & 200 & 102 & 51 & 10 & 5 & 88 & 44 & 73.72 \\
\hline 4 & $\begin{array}{l}\text { I think e-learning is essential } \\
\text { for education. }\end{array}$ & 200 & 104 & 52 & 10 & 5 & 86 & 43 & 74.68 \\
\hline 5 & $\begin{array}{l}\text { I enjoy lessons which embede } \\
\text { an e-learning. }\end{array}$ & 200 & 136 & 68 & 44 & 22 & 20 & 10 & 112.48 \\
\hline 6 & $\begin{array}{l}\text { I feel comfortable working } \\
\text { with computer. }\end{array}$ & 200 & 106 & 53 & 24 & 12 & 70 & 35 & 50.68 \\
\hline 7 & $\begin{array}{l}\text { The more often I use } \\
\text { computer, the more I will } \\
\text { enjoy. }\end{array}$ & 200 & 112 & 56 & 47 & 23.5 & 51 & 50.5 & 40.31 \\
\hline
\end{tabular}

(C) 2018 HEAN 


\begin{tabular}{|c|c|c|c|c|c|c|c|c|c|}
\hline 8 & $\begin{array}{l}\text { I have better information } \\
\text { sources than e-learning. }\end{array}$ & 200 & 0 & 0 & 6 & 3 & 194 & 97 & 298.41 \\
\hline 9 & $\begin{array}{l}\text { E-learning is very helpful in } \\
\text { learning process. }\end{array}$ & 200 & 109 & 54.5 & 13 & 6.5 & 78 & 39 & 72.01 \\
\hline 10 & Computers scare me. & 200 & 6 & 3 & 15 & 7.5 & 179 & 89.5 & 284.53 \\
\hline 11 & $\begin{array}{l}\text { I need help from teachers to } \\
\text { learn with e-learning. }\end{array}$ & 200 & 34 & 17 & 24 & 12 & 142 & 71 & 128.44 \\
\hline 12 & Computers are difficult to use. & 200 & 16 & 8 & 10 & 5 & 174 & 87 & 259.48 \\
\hline 13 & $\begin{array}{l}\text { Using e-learning is time } \\
\text { consuming. }\end{array}$ & 200 & 101 & 50.5 & 53 & 26.5 & 46 & 23 & 26.89 \\
\hline 14 & $\begin{array}{l}\text { Working with computer makes } \\
\text { me nervous. }\end{array}$ & 200 & 9 & 4.5 & 86 & 43 & 105 & 52.5 & 77.53 \\
\hline 15 & $\begin{array}{l}\text { I wish e-learning is unwanted } \\
\text { to use for teaching. }\end{array}$ & 200 & 0 & 0 & 26 & 13 & 174 & 87 & 197.61 \\
\hline
\end{tabular}

In response to the first statement, the significant with $\chi 2$-value is 100.69 at 0.05 level of significance and $66.5 \%$ students have agreed saying that the response is positive, $13 \%$ students are neutral and 20.5\% students are disagreed with this statement. This shows that most of the students have agreed that using e-learning at school/college improves learning. In response to this statement students said, "We can improve our health and population education if the school/college provides e-learning and teach us through it."

In response to the second statement, the significant with $\chi 2$-value is 149.08 at 0.05 level of significance and $72 \%$ students are agreed i.e. the response is positive, $3 \%$ students are neutral and $25 \%$ students are disagreed with this statement. This shows that most of the students are agreed with the statement that e-learning makes learning more interesting. At that time the students replied, "Like in other subject's now I do not have problem in quantitative techniques regarding the missing contents because I can easily recover those contents by watching the video".

In response to the third statement, the significant with $\chi 2$-value is 73.72 at 0.05 level of significance and $51 \%$ students are agreed i.e. the response is positive, $5 \%$ students are neutral and $44 \%$ students are disagreed with this statement. This shows that the majority of students are agreed with the statement 'I can get access to computers at school/college whenever I need.' They said, 'We have sufficient amount of e-learning materials in our school/college and we can use them whenever needed."

In response to the fourth statement, the significant with $\chi 2$-value is 74.68 at 0.05 level of significance and $52 \%$ students are agreed i.e. the response is positive, $5 \%$ students are neutral and $43 \%$ students are disagreed with this statement. This shows that majority of students have agreed that ICT is essential for education. They replied that 'e-learning is very essential in the modern context of learning.'

In response to the fifth statement, the significant with $\chi 2$-value is 112.48 at 0.05 level of significance and $68 \%$ students are agreed i.e. the response is positive, $22 \%$ students are neutral and $10 \%$ students are disagreed with this statement. This shows that most of the students are agreed with the statement 'I enjoy lessons with computer." Some students said that they become very interested when they are taught with computer."

In response to the sixth statement, the significant with $\chi^{2}-$ value is 50.68 at 0.05 level of significance and $53 \%$ students are agreed i.e. the response is positive, $12 \%$ students 
are neutral and 35\% students are disagreed with this statement. This shows that majority of students are agreed with this statement. They replied that it is very comfortable to use computer and learn through it.

In response to the seventh statement, the significant with $\chi^{2}$-value is 40.31 at 0.05 level of significance and $56 \%$ students are agreed i.e. the response is positive, $23.5 \%$ students are neutral and $25.5 \%$ students are disagreed with this statement. This shows that majority students are agreed with the statement, 'I believe that the more often teachers use computers, the more I will enjoy school /college.'

In response to the eighth statement, the significant with $\chi 2$-value is 298.41 at 0.05 level of significance and $3 \%$ students are neutral while $97 \%$ students are disagreed i.e. the statement was negative. This shows that the most of students are disagreed with the statement, 'I have better information sources than e-learning.'

In response to the ninth statement, the significant with $\chi 2$-value is 72.01 at 0.05 level of significance; and $54.5 \%$ students are agreed i.e. the response is positive, $6.5 \%$ students are neutral and 39\% students are disagreed with this statement. This shows that majority students have agreed that 'e-learning is very helpful in learning process.'

In response to the tenth statement, the significant with $\chi 2$-value is 284.53 at 0.05 level of significance and 3\% students are agreed, $7.5 \%$ students are neutral and $89.5 \%$ students are disagreed i.e. the statement was negative. This shows most of the students are disagreed with the statement, 'Computers scare me.'

In response to the eleventh statement, the significant with $\chi 2$-value is 128.44 at 0.05 level of significance and $17 \%$ students are agreed, $12 \%$ students are neutral and $71 \%$ students are disagreed i.e. the statement was negative. This shows that most of the students are disagreed with the statement, 'I need more and more help from teachers to learn e-learning.'

In response to the twelfth statement, the significant with $\chi 2$-value is 259.48 at 0.05 level of significance and $8 \%$ students are agreed, $5 \%$ students are neutral and $87 \%$ students are disagreed i.e. the statement was negative. This shows that the most of students are disagreed with the statement, 'computers are difficult to use.'

In response to the thirteenth statement, the significant with $\chi 2$-value is 26.89 at 0.05 level of significance and $50.5 \%$ students are agreed i.e. the response is positive, $26.5 \%$ students are neutral and $23 \%$ students are disagreed with this statement. This shows that most of the students are agreed with the statement, 'It is time consuming using e-learning in learning. '

In response to the fourteenth statement, the significant with $\chi^{2}$-value is 77.53 at 0.05 level of significance and $4.5 \%$ students agreed, $43 \%$ students are neutral and 52.5\% students disagreed i.e. the response is negative with this statement. This shows that the most of students are disagreed 'Working with computers makes me nervous.'

In response to the fifteenth statement, the significant with $\chi 2$-value is 197.61 at 0.05 level of significance and 13\% students are neutral and $87 \%$ students disagreed i.e. the response is negative with this statement. This shows that most of the students are disagreed 'e-learning is unwanted to use for teaching.'

\section{Discussion}

The above data show that the use of e-learning can change teaching techniques in several ways. With e-learning, teachers are able to create their own materials and thus have more control over the materials used in the classroom than they have had in the past. 
Students associated with e-learning would raise interest and increased motivation on their part. Interactive courseware was popular amongst students - particularly games and simulations seen as combining practical challenges with learning opportunities. Some comments suggested that such interest and motivation led not just to harder work on the part of pupils but to a changed quality of engagement. Students also saw e-learning tools as helpful to overcome the difficulties they experienced in producing work to a good standard - notably where this involved scribing by hand - so also reducing scope for criticism by teachers. Equally however, without the capacities required, ineffective use of e-learning tools could be highly de-motivating to the students. For some students, use of e-learning tools could diminish the sense of capability and accomplishment they gained from carrying out tasks without assistance.

According to the theory of constructivism, knowledge is not taught but is learned by the learner themselves through constructing new knowledge on the basis of old knowledge, under a certain setting, with the help of others such as teachers or study partners, and utilizing certain study resources. Students being the centre of teaching and learning process while teacher works as organizer, facilitator and motivator, utilizing setting, cooperation and dialogue to motivate students for self and better learning.

\section{Conclusion}

It can be concluded that the attitudes of student's towards use of e-learning materials in health and population education at higher secondary school/ college level in Kathmandu valley is significantly positive. They are in favour of using e-learning. Their responses show that e-learning is needed for better learning to take place.

Only a negligible number of students have negative perceptions, misconceptions, misunderstanding and illusions towards e-learning. School/college students believe in e-learning whether it increases student's health and population education achievement and learning.

Students were enthusiastic in learning health and population education with the help of e-learning. The various aspects of e-learning tools visually, dynamic in nature help students to provide more depth understanding of quantitative techniques. The students received immediate feedback with the help of e-learning. Students were very much impressed and excited to know about the quantitative techniques based on software. They also emphasize in publicizing the information about e-learning throughout the country. It appeared that e-learning can be a useful tool that can be interpreted for teaching and learning of health and population education at higher secondary schools/college in Nepal.

It is obvious that in general information technology and in particular, calculators, computers and softwares do not actually mean major changes in how to teach rather than what to teach. A typical way does so is to replace older ways of communication with new possibilities offered by information technology and the internet. The use of web pages to disseminate information and e-mail for two-way communication with students can be very effective as it can reduce time, costs needed to transfer information and also noise in communication. In this regard, the former teacher centred educational activities began to turn into learner-centred activities. Thus, e-learning helps the students to become more active in the education process. Particularly, calculators and computer technology have also a great potential to affect presenting the contents of the higher secondary school/college level health and population education. 
So, the researcher comes to the conclusion that perception about any system, process and event depends upon the knowledge and clear understanding about it. It is recommended that there is necessity of training, orientation and discussion programs about e-learning to apply in teaching health and population education. Moreover, the researcher comes to the conclusion that government, MOE, CDC and other concerned bodies should provide information about the implementation of E-learning in higher secondary level.

\section{REFERENCES}

Best, J.W. and Kahn J.V. (2009).Research in education (10 ${ }^{\text {the }}$ d.). New Delhi: Phi Learning Private Limited.

Horton, W. (2001), "leading e-learning", American society for training a Development. Retrieved from URL:http/www.elearninggurus.com/ articals.Html (Accessed in June, 2001).

Kaling, H.M. (2007). Critical success factors for e-learning acceptance: Conwrmtory factors models. New Delhi: Sage Publication.
Mayes, T. (2004). "Review of e-learning theories framework and models" JISC e-learning models Desk study, Retrieved from URL:http//www. Jisc.ac.uk/uploadeddocuments/stagelearning models version 201.pdf (accessed in June, 2001).

Ministry of Education. (2013). Information, communication and technology in education master plan 2013-2017. Kathmandu: MOE.

Sapkota, B.K. (2015). Effectiveness of information communication technology integrated pedagogy at secondary level. Himalayan Journal, Vol. 5, 2016, pp. 68-76.

Selim, H.M. (2008). An empirical Investigation of student acceptance of a course. Website 'computers and education 40(4): 343-360'

Sparacia, W.J. (2007). The effect of using a computer on the seventh grade students' achievement in mathematics and their teacher attitudes towards using it as a learning mean. Mathematical Society, Chhenai, India.

Zeitoun, H. (2008). E-learning: Concept, issues, application, evaluation, Riyadh: DarAlsolateah Publication.

www.efrontlearning.net

www.talentlms.com 